\title{
Analysis of the Communication Mode of Internet Rumors: Taking Top Ten Online Rumors about COVID-19 Epidemic in China in April as Examples
}

\begin{abstract}
WU Chutian ${ }^{1 *}$
${ }^{1}$ The Park School, 2425 Old Court Road, Baltimore, MD 21208, USA

*Wuchutian. Email: wangqixin3@126.com

ABSTRACT

At the beginning of 2020, the emergence of COVID-19 had a huge impact all over the world, followed by a large number of rumors about the epidemic, and caused panic among the people and society. This article focuses on the analysis of ten typical Internet rumors about COVID-19 epidemic in China in April, and explores the spreaders, media, content, channels, audiences and effects of online rumors under the framework of the $5 \mathrm{~W}$ model research theory. In this way, this study will explore the communication mode of online rumors and the psychology of the masses in the post-epidemic era, and proposes reasonable suggestions for governance of online rumors from the audience, social media, and government levels.
\end{abstract}

Keywords: COVID-19, online rumors, communication, mass psychology, solution

\section{BACKGROUND}

At the beginning of 2020, COVID-19 began to attract the attention of people around the world with its alarming rate of infection and deadly symptoms of infection. The unknown caused by COVID-19 has gradually transformed into panic among the people, and this has turned into wanton public opinion and rumors in society on a large scale. A large number of online self-media took this opportunity to create a large number of rumors for personal benefit, not motivated by the communication of true information. The spread speed and harmfulness of rumors include factors such as panic among the people, chaos in social order, and distrust of the government, which are no less than the impact of COVID-19. This phenomenon has largely played a negative role in the official media's efforts to refute rumors and has become a major governance problem during the COVID-19 epidemic. Analyzing the spread of COVID-19 rumors is helpful to understand the cause and effect of the whole public opinion.

Regarding the definition of rumors, domestic and foreign scholars have proposed related theories and explanations. French scholar Jean-Noël Kapferer put forward the definition of rumors in his book le plus vieux média du monde: "The propositions related to the events at the time are meant to make people believe, usually in the form of oral media. It is circulated among people, but the lack of specific information has confirmed its accuracy, and it has been widely circulated without official confirmation." [1] The famous American psychologist Gordon Willard Allport put forward the mechanism of making and communicating rumors. He pointed out that people are prone to feelings of terror and tension when they lack reliable information, uneasy and worried, and society is in a crisis state, and rumors are the easiest to spread [2]. Chinese scholars such as Guo Qingguang proposed that rumors are deliberately fabricated news or information [3]. Luan Yushu proposed that "rumors are created by a certain motive, spreading false information without factual basis, exaggerating or distorting facts." [4] Fan Min and Zhou Jianxin combined the opinions of most scholars and proposed that rumors must meet two characteristics: first, information must originate from a social public problem; second, these unsubstantiated or falsified news need to be widely spread [5]. In addition, Zhang Hongguang and other scholars pointed out that Internet rumors are characterized by low cost, high speed, strong harm and deep influence [6]. According to the above scholars' point of view, and based on rumors of COVID - 19 outbreak period, this paper put forward the definition. This paper holds that the Internet rumors of COVID - 19 during the outbreak is appeared and spread in society, without 
official confirmed publicly or have been rumors that the official, the network information related to the COVID 19 , and produce certain influence to the society.

This paper will study the communication process and governance of rumors related to COVID - 19 on the Internet, using the "5W model" theory as the research theory and research framework, taking 10 typical rumors in April in the post-epidemic era in China as examples and analyzing the basis of discussing its communication channels, communication content and communication effects, and further thinking about the governance countermeasures of Internet rumors.

\section{THE COMMUNICATION CHANNELS AND CONTENT OF INTERNET RUMORS}

The American scholar H. Laswell first proposed five basic elements of the communication process in his paper "The Structure and Function of Communication in Society" in 1948, which is: Who, says what, in which channel, to whom and with what effect [7] . This paper will focus on this model to comprehensively analyze the propagation mode and influence of top ten rumors in April in China on the Internet, so as to analyze the psychological activities of people in the post-epidemic era.

The data for the top ten rumors in April mainly comes from the China Internet joint anti-rumor platform [8] . This article uses the data to analyze the specific communication channels, content and effects of Internet rumors in the post-epidemic era.

First of all, with regard to the communication channels, online rumors during the epidemic mainly spread through Weibo, WeChat and other Internet news platforms. As the most important public figure, public information release and communication platform in mainland China, Weibo's large number of active users and extensive information sharing provide a very suitable environment for rumor spreading during the epidemic. Compared with WeChat, WeChat is used in a more private and independent way. WeChat Official account with an exclusive subjective and complete article communication mode, can easily win the trust of followers, so as to achieve the effect of one to ten to one hundred in the circle of friends. The speed of spreading online rumors is also not to be underestimated.

Secondly, as for the content of communication, the top ten online rumors in April are: food shortage, hurry to hoard rice and grab oil; The commencement time of school and each grade in Beijing is determined; COVID19 antibodies protect against "secondary infections"; 5G causes the spread of COVID-19; Zhong Nanshan predicted "a full outbreak in May"; The COVID-19 is originated from Wuhan Lab; The time to remove masks has been decided; Russia will expel Chinese citizens on a large scale; Hubei agricultural products infected with the COVID-19; China supplies low-quality testing kits to the US.

Moreover, these online rumors are multi-faceted and representative. The rumors range from "Chasing the Wind and Clutching at Shadows", "Pseudoscience", "Creating Something out of Nothing" , "Absurdity" , "Celebrity effect", “Erroneously Spreading the Wrong Words" , “Creating Panic”, "Vilification”, etc and spread false information from multiple angles and routines. But the features of these rumors also correspond to the public's mentality about the epidemic. The specific content of these online rumors and their features are shown in the Table 1:

It can be concluded from the above that the reason why Internet rumors appear and spread on a large scale during the COVID-19 epidemic is that they can deeply grasp the psychology of the audience, such as panic, anxiety, curiosity and patriotism, as well as their low media literacy. Rumour makers increase the credibility of rumors through celebrity effect, and use the curiosity of the audience to catch rumors and spread rumors on the Internet. Meanwhile, online rumors arouse public opinion by taking advantage of the patriotic sentiments of the audience and spreading online rumors by wilfully smearing the relations between China and other countries. In addition, due to the insufficient media and scientific literacy of Internet users, they are more likely to believe some things out of thin air, as well as absurd knowledge and even pseudoscience.

Table 1 Rumor content and features on the Internet

\begin{tabular}{|l|l|l|}
\hline Number & \multicolumn{1}{|c|}{ Rumor content } & \multicolumn{1}{|c|}{ Rumor features } \\
\hline 1 & With food in short supply, people need to hoard rice and grab oil & Creating panic \\
\hline 2 & $\begin{array}{l}\text { The commencement time of school and each grade in Beijing is } \\
\text { determined }\end{array}$ & $\begin{array}{l}\text { Chasing the Wind and } \\
\text { Clutching at Shadows }\end{array}$ \\
\hline 3 & COVID-19 antibodies protect against "secondary infections" & Pseudoscience \\
\hline 4 & 5 G causes the spread of COVID-19 & Absurdity \\
\hline 5 & Zhong Nanshan predicted "a full outbreak in May"' & Celebrity effect \\
\hline
\end{tabular}




\begin{tabular}{|l|l|l|}
\hline 6 & The COVID-19 is originated from Wuhan Lab & $\begin{array}{l}\text { Creating Something out of } \\
\text { Nothing }\end{array}$ \\
\hline 7 & The time to remove masks has been decided & $\begin{array}{l}\text { Erroneously Spreading the } \\
\text { Wrong Words }\end{array}$ \\
\hline 8 & Russia will expel Chinese citizens on a large scale & $\begin{array}{l}\text { Chasing the Wind and } \\
\text { Clutching at Shadows }\end{array}$ \\
\hline 9 & Hubei agricultural products infected with the COVID-19 & Creating Panic \\
\hline 10 & China supplies low-quality testing kits to the US & Vilification \\
\hline
\end{tabular}

\section{THE TYPE OF INTERNET RUMORS}

In the post-epidemic era, the types of internet rumors also change with the changes in the contents of internet rumors. In conclusion, the public's focus will shift from COVID-19 prevention and treatment to the post-COVID19 social development and international situation.

Dang Ximin pointed out that various kinds of rumors appeared during the epidemic, which could be subdivided into health care rumors, sad rumors, horror rumors, conspiracy theory rumors, public safety rumors, wellintentioned rumors, "positive" rumors, over-amplified rumors, etc [9]. Qian Yingfei analyzed 437 samples from the rumor refuting platform, and pointed out that among the 437 rumors during the epidemic, 135 of them were "precautionary measures", accounting for $31 \%$ of all rumors. Rumors of "prevention and control measures" were followed by 47 , accounting for 11 per cent. In addition, there were 43 "risk of infection" and "foreignrelated rumors", accounting for $10 \%$ each [10] . It can be seen that rumors during the epidemic mainly focus on prevention methods, prevention governance and control measures and infection risks.

The ten online rumors about April can be further analyzed and classified into four categories: social livelihood, source of virus, foreign relations, and followup development of the epidemic. Among them, the COVID-19 on food shortage and the spread of agricultural products in Hubei can be classified into the social livelihood category, which reflects the importance and concern of the general public for the basic needs of life in the special period. Similar rumors such as that the COVID-19 originated from a lab in Wuhan belong to people's problems about the origin and spread of the virus, which is reflected in the fear of a new outbreak and curiosity about the source of the epidemic in the easing stage of the epidemic. Rumors such as Russia's mass expulsion of Chinese citizens and China's supply of lowquality testing kits to the United States fall into the category of diplomatic relations. Such rumors can be eyecatching and reflect the concern of some Chinese citizens about the social environment in China and the importance of the global situation. Secondly, such rumors as COVID19 antibodies can be prevented from secondary infection, Zhong Nanshan predicted that "the epidemic will fully break out in May", and the timing of mask removal events across China can be classified as the follow-up development of the epidemic. It is not difficult to see that people are anxious about the alleviation of the epidemic and eager to see an early end to the epidemic. The specific types of online rumors and corresponding content are shown in Table 2.

This shows that in the post-epidemic era, people are paying more attention to issues such as people's livelihood, the source of the virus, foreign relations and the follow-up development of the epidem.

Table 2 Rumour types and content on the Internet

\begin{tabular}{|c|c|c|c|}
\hline Rumor type & Rumor content & Rumor type & Rumor content \\
\hline \multirow[b]{2}{*}{ Social livelihood } & $\begin{array}{l}\text { With food in short supply, people } \\
\text { need to hoard rice and grab oil }\end{array}$ & \multirow{4}{*}{$\begin{array}{l}\text { Follow-up } \\
\text { development of } \\
\text { the epidemic }\end{array}$} & $\begin{array}{l}\text { COVID-19 antibodies protect } \\
\text { against "secondary infections" }\end{array}$ \\
\hline & $\begin{array}{l}\text { Hubei agricultural products infected } \\
\text { with the COVID-19 }\end{array}$ & & $\begin{array}{l}\text { The commencement time of school } \\
\text { and each grade in Beijing is } \\
\text { determined }\end{array}$ \\
\hline \multirow[b]{2}{*}{ Virus source } & $5 G$ causes the spread of COVID-19 & & \multirow{2}{*}{$\begin{array}{l}\text { The time to remove masks has been } \\
\text { decided }\end{array}$} \\
\hline & $\begin{array}{l}\text { The COVID-19 is originated from } \\
\text { Wuhan Lab }\end{array}$ & & \\
\hline
\end{tabular}




\begin{tabular}{|l|l|l|l|}
\hline $\begin{array}{l}\text { Diplomatic } \\
\text { relations }\end{array}$ & $\begin{array}{l}\text { Russia will expel Chinese citizens } \\
\text { on a large scale }\end{array}$ & $\begin{array}{l}\text { China supplies low-quality testing } \\
\text { kits to the US }\end{array}$ & $\begin{array}{l}\text { Zhong Nanshan predicted "a full } \\
\text { outbreak in May" }\end{array}$ \\
\hline
\end{tabular}

\section{COMMUNICATION EFFECTS OF INTERNET RUMORS}

In terms of audiences and communication effects, the number of relevant information in the top ten rumors in April represents the amount of reading, reposting and attention of audience online. This index means the spread and effectiveness of a certain online rumor. By adding up the number of relevant information about the content of different online rumors according to their type, a statistical Table 3 is made for analysis.
The above table shows that the number of online rumors related to the follow-up development of the epidemic has the most information, indicating that netizens are most concerned about issues related to the follow-up epidemic. The number of rumors related to social and people's livelihood ranks second, indicating that although it has been four months, netizens are still worried about daily life. The number of rumors related to virus sources and diplomatic relations is less than the previous two types of rumors, indicating that netizens pay less attention to the two types.

Table 3 The number and amount of relevant information of rumors

\begin{tabular}{|c|c|c|c|}
\hline $\begin{array}{l}\text { Rumors } \\
\text { type }\end{array}$ & Rumor content & $\begin{array}{l}\text { The number of } \\
\text { relevant information }\end{array}$ & $\begin{array}{l}\text { Total amount of the } \\
\text { number of relevant } \\
\text { information }\end{array}$ \\
\hline \multirow{2}{*}{$\begin{array}{l}\text { Social } \\
\text { livelihood }\end{array}$} & $\begin{array}{l}\text { With food in short supply, people need to hoard } \\
\text { rice and grab oil }\end{array}$ & 437186 & \multirow{2}{*}{464724} \\
\hline & $\begin{array}{l}\text { Hubei agricultural products infected with the } \\
\text { COVID-19 }\end{array}$ & 27538 & \\
\hline \multirow{2}{*}{ Virus source } & $5 G$ causes the spread of COVID-19 & 197448 & \multirow{2}{*}{347647} \\
\hline & The COVID-19 is originated from Wuhan Lab & 150199 & \\
\hline \multirow{2}{*}{$\begin{array}{l}\text { Diplomatic } \\
\text { relations }\end{array}$} & $\begin{array}{l}\text { Russia will expel Chinese citizens on a large } \\
\text { scale }\end{array}$ & 38568 & \multirow[t]{2}{*}{50900} \\
\hline & China supplies low-quality testing kits to the US & 12332 & \\
\hline \multirow{4}{*}{$\begin{array}{l}\text { Follow-up } \\
\text { development } \\
\text { of the } \\
\text { epidemic }\end{array}$} & $\begin{array}{l}\text { COVID-19 antibodies protect against "secondary } \\
\text { infections" }\end{array}$ & 205187 & \multirow{4}{*}{869580} \\
\hline & $\begin{array}{l}\text { The commencement time of school and each } \\
\text { grade in Beijing is determined }\end{array}$ & 384671 & \\
\hline & The time to remove masks has been decided & 98179 & \\
\hline & Zhong Nanshan predicted "a full outbreak in May" & 181543 & \\
\hline
\end{tabular}

The top ten online rumors in April accurately achieved the effect of short-term wide-range browsing. The main reason is that these rumors have captured the main concerns of people in the post-epidemic era. From the large amount of browsing and forwarding data, it is not difficult to see that the issues that netizens are most concerned about are social livelihoods and subsequent social development. Rumors covering similar content can be produced at a very low cost and in large quantities because of the high-expected psychology of the masses and the uncertainty of the truth, so they can achieve the effect of wanton communication.

\section{CONCLUSION}

In general, the rapid development of information in today's society provides an excellent communication environment for all kinds of rumors. Social platforms and other network public platforms such as We-Media Official Accounts can be a way for online rumors to spread quickly. Rumor spreaders will take their own interests as their starting point, in order to win the public's 
attention, get more views, and produce content that is not verified by official channels but is of concern to the public. The diversity of various online rumors can usually achieve an effect of disrupting social order and increasing social panic.

We should deal with the reduction and control of online rumors from the rumor posters and spreaders. Rumor posters and spreaders should attach importance to their social responsibilities as citizens, realize the negative impact of online rumors on the society, and strengthen the cultivation of their own qualities. For Internet users, improving their media literacy and selfcognition of different events can greatly help them to distinguish the true from the false, so as to avoid following the crowd and greatly reduce the propagation efficiency of online rumors. As for the media, they should assume social responsibility and release true and objective news and information. For the national government, the most important thing is to establish an official online rumor refuting platform and to monitor the rumor environment on the Internet in real time, so as to timely respond to the rumor spreading before it reaches its peak and reduce social panic.

\section{REFERENCES}

[1] Jean-Noel Capferre, Capferre, \& Zheng Ruolin. (2008). Rumor: The world's oldest media. Shanghai People's Publishing House.

[2] Chen, P. (2010). The news value and public opinion orientation of epidemic reports. News Communication, 000(005), P.58-59.

[3] Guo, Q. G. (2011). Communication Course. 2nd edition. Renmin University of China Press.

[4] Luan, Y. S. (2020). Research on the characteristics of the spread of rumors of the new crown pneumonia epidemic and its governance mechanism-a comprehensive analysis of 318 cases of rumors during the new crown pneumonia epidemic. News Research Guide, 011(006), 6869,104 .

[5] Fan, M. \& Zhou, J. M. (2020). Information distortion and power game: The generation and communication mechanism of online rumors in a major epidemic. News and Communication Review (4).

[6] Zhang, H. G., Bai, G. \& Mao, Q. L. (2020). The mode of spreading online rumors during the new crown pneumonia epidemic. Youth Journalist (18), 44-45.

[7] Guo, Q. G. (2002). Communication Course-21st Century Journalism and Communication Series
Textbook-National Key Textbook. Renmin University of China Press.

[8] China Internet Joint Rumor Refusal Platform. (2020). Inventory of the top ten rumors in April. Don't be deceived by rumors about the epidemic. China Information Security (05), 10-11.

[9] Dang, X. M. (2020). Analysis of rumors during the new crown pneumonia epidemic. Young Journalist (21), 43-44.

[10] Qian, Y. Y. (2020). Research on rumors during the new crown pneumonia epidemic_-Based on the analysis of 437 samples of the "Fruit" rumor-relief platform. Audiovisual (08), 132-133. 